\title{
The Effects of Curcumin on Sperm Parameters and Nitric Oxide Production in Varicocelized Rats
}

\author{
Efectos de la Cúrcuma sobre los Parámetros Espermáticos y \\ Producción de Óxido Nítrico en Ratas Varicocelizadas
}

Melika Izadpanah"; Rafieh Alizadeh"*; Mohammad Bagher Minaee*; Leyla Heydari"; Adebayo Babatunde* \& Mehdi Abbasi"

IZADPANAH, M.; ALIZADEH, R.; MINAEE, M. B.; HEYDARI, L.; BABATUNDE, A. \& ABBASI, M. The effects of curcumin on sperm parameters and nitric oxide production in varicocelized rats. Int. J. Morphol., 33(4):1530-1535, 2015.

SUMMARY: One of the proposed mechanism by which varicocele induces its damage is excessive release of nitric oxide (NO). Several studies have shown the role of NO in poor sperm quality in infertile patients with varicocele. Scientific studies have demonstrated the beneficial effects of curcumin on the sperm parameters. Curcumin as an atoxic antioxidant can reduce production of NO. The aim of this study was to determine the effect of curcumin on NO levels and investigate if curcumin can improve sperm parameters in varicocelized male rats. Thirty male Wistar rats were randomly divided into 5 groups (V1 and V2 (varicocele), T (treatment), Sh (sham) and C was control). In groups V1, V2, T and Sh, the left renal vein was partially ligated to induce varicocele. In groups V1 and V2, sperm parameters and NO level were evaluated 8 and 16 weeks respectively after varicocele induction. Groups T and Sh received $100 \mathrm{mg} / \mathrm{kg}$ curcumin and placebo respectively, daily for 8 weeks after 2 months of induced varicocele. Sperm parameters (count, motility, viability and morphology), epididymis and testis weight and also NO concentration were measured. Sperm parameters (count, motility and viability) in groups V1, V2 and Sh were significantly low in comparison with control and treatment groups. The level of NO was significantly increased in serum of rats in groups V1 and V2, whereas group T rat serum in which curcumin was administered, showed decreased NO levels. The values of the epididymis and testis weight had no significant changes $(\mathrm{P} \leq 0.05)$ in all groups. Administration of curcumin as a free radical scavenger, can decrease NO level and improve sperm parameters in varicocelized male rats.

KEY WORD: Varicocele; Curcumin; Sperm parameters; Rat.

\section{INTRODUCTION}

Varicocele is the most frequent abnormal physical finding in men. There are studies showing a negative impact on testicular function already in adolescence (Romeo et al., 2001). The mean incident of varicocele is approximately $15 \%$ to $20 \%$ in healthy men, and interestingly increases to $40 \%$ to $70 \%$ in men with primary and secondary infertility, so is the most common identifiable cause of infertility in men (Baazeem et al., 2011; Schauer et al., 2012). The etiology of varicocele is controversial, but three theories on the cause of varicocele are accepted. The first theory is the anatomical differences between the left and right testicular veins; specifically that the right vein inserts into the inferior vena cava directly, while the left testicular vein inserts into the left renal vein. The difference in insertion of the left testicular vein is believed to have resulted in an increase in hydrostatic pressure which is transmitted subsequently to the pampiniform plexus and causing dilatation and tortuosity of the veins. Secondly, the absence of competent venous valves, resulting in reflux of venous blood. Thirdly, the presence of a partial obstruction of the testicular vein caused by the location of the left renal vein when passing through the angle between the abdominal aorta and the superior mesenteric artery. It is likely that the etiology is multifactorial (Marmar, 2001; Eisenberg \& Lipshultz, 2011). Oxidative stress (OS) is a pathological condition of serious imbalance between production of reactive oxygen species (ROS) and antioxidant enzymes level. ROS is considerably correlated with sperm parameters quality and thus infertility in men (Sikka et al., 1995).

Recent studies in subfertile men with idiopathic varicocele have shown the existence of an excessive release of nitric oxide $(\mathrm{NO})$ within dilated spermatic veins (Romeo et al.). NO is a free radical gaseous molecule that is produced

\footnotetext{
* Department of Anatomy, School of Medicine, Tehran University of Medical Sciences, Tehran, Iran.

** Department of Anatomy, School of Medicine, Iran University of Medical Sciences, Tehran, Iran.
} 
in cells from guanidine nitrogen of L-arginine by three isoforms of nitric oxide synthase (NOS), neuronal NOS (nNOS), endothelial NOS (eNOS), and inducible NO synthase (iNOS) (Aksoy et al., 2000). NO physiologically regulates multiple important functions within the male reproductive system, But under pathologic conditions, an excessive release of NO can have adverse effects on both sperm and testis function and steroidogenesis (Aksoy et al.; Romeo et al.). Curcumin is contained in the rhizome of the plant Curcuma longa Linn. Many studies have shown that curcumin as a free radical scavenger inhibits nitric oxide and reactive oxygen species (ROS) production in macrophages, especially in testicular tissue. So it is believed that Curcumin may stop peroxidative alteration in the sperm and the testicular membrane which leads to enhancement of sperm motility and decrease in spermatozoa defects (Oguzturk et al., 2012; Noorafshan \& Ashkani-Esfahani, 2013). The effects of Curcumin on varicocele have not been reported yet. The purpose of this study was to show that Curcumin improves sperm quality in varicocelized male rats. The NO level, sperm parameters, weights of testis and epididymis were evaluated before and after Curcumin administration.

\section{MATERIAL AND METHOD}

Animal Groups and Varicocele Induction. A total of 30 adult male Wistar rats weighing between 250 and $300 \mathrm{~g}$ were used. The animals were housed under standard laboratory conditions (12-h light: 12 -h dark cycle at $22^{\circ} \mathrm{C}$ ). Male rats were randomly divided into 5 groups (V1 and V2 (varicocele), $\mathrm{T}$ (treatment), Sh (sham), and C (control) with 6 rats in each of the groups. The rats in groups V1, V2, T, and Sh underwent a left experimental varicocele. Group $\mathrm{C}$ rats were used as the control group. The sperm parameters of groups V1 and V2 were evaluated 8 and 16 weeks respectively after varicocele induction. Rats in groups $\mathrm{T}$ and Sh were administered 100 $\mathrm{mg} / \mathrm{kg}$ Curcumin and placebo by oral gavage, respectively, daily for 8 weeks after varicocele induction.

Surgical Procedure. Left varicocele was experimentally induced in the rats of groups V1, V2, T, and Sh, as described by Turner (2001). In brief, rats were weighed and administered general anesthesia with an intraperitoneal injection of ketamine $(100 \mathrm{mg} / \mathrm{kg}$ body weight $)$ and xylazine $(1 \mathrm{mg} / \mathrm{kg}$ body weight) (Cam et al., 2004). Through a midline incision, the left renal vein was dissected and then ligated partially with a 3-0 silk placed medial to the insertion of the left adrenal vein. The needle was removed carefully, and the diameter of the left renal vein was reduced by approximately $50 \%$ (Turner) (Fig. 1).

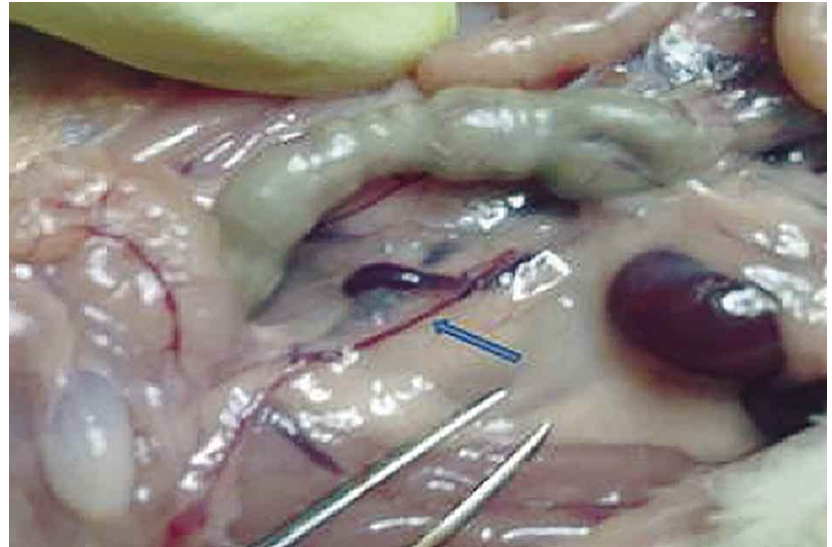

Fig. 1. Spermatic vein. Distended spermatic vein in a varicocele rat (arrow).

Treatment. Eight weeks after surgery, group $\mathrm{T}$ rats received $100 \mathrm{mg} / \mathrm{kg}$ of Curcumin (Oguzturk et al.) (Sigma/ Aldrich Chemical Co.) for 8 weeks. The drug was dissolved in corn oil (Farombi et al., 2007; Oguzturk et al.) and was immediately administered via gavage techniques. The sperm parameters of groups V1 and V2 were evaluated 8 and 16 weeks after surgery respectively and groups $\mathrm{T}$ and Sh were evaluated 16 weeks after varicocele induction (8 weeks after treatment).

Sperm Collection and Analysis. By laparotomy, the epididymis and testes in left and right were removed immediately and epididymis was separated from the testes carefully. The weights of testes and epididymis were recorded. The caudal parts of the both right and left epididymis were minced in $5 \mathrm{ml}$ of Hanks' medium, and incubated for $15 \mathrm{~min}$. The diluted sperm suspension $(10 \mathrm{ml})$ was transferred to the hemocytometer, and the settled sperms were counted with a light microscope at x40 magnification (million/ml) (Cheng et al., 2006). Sperm motility was analyzed microscopically (Olympus IX70) [x40 magnification] in 10 fields according to the World Health Organization recommended method. Sperm viability was performed by the eosin Y staining. 20 microliter of freshly liquefied semen was mixed with 5 microliter of $1 \%$ eosin Y. A smear was made by placing a drop of mixture on a clean glass slide and allowed to air dry. The prepared slide was examined using a light microscope. Pink-stained were counted as dead sperm and unstained live sperm were counted in 10 fields (Fig. 2 ), and there numbers were recorded (Khaki et al., 2010). The total sperm with normal morphology was expressed as percentage incidence (no head, double head, double tail, bent tail, bent neck and amorphous were mentioned as abnormal morphology) (Alizadeh et al., 2010) (Fig. 3). 


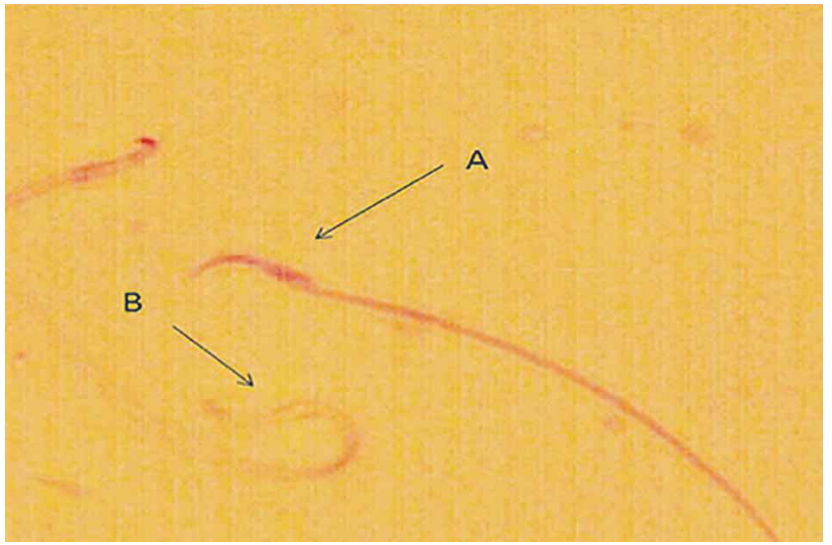

Fig. 2. Sperm viability. A: Dead sperm, B: Viable sperm.

NO analysis. The measurement of NO is rather difficult since $\mathrm{NO}$ is a molecule with a short half -life that is rapidly converted to the oxidation products nitrite $\left(\mathrm{NO}_{2}^{-}\right)$and nitrate $\left(\mathrm{NO}_{3}^{-}\right)$(Aksoy et al.), so Griess reagent were used for measuring these products. Blood samples were taken from the inferior vena cava of rats into the micro tube and centrifuged at $10,000 \mathrm{~g}$ at $4{ }^{\circ} \mathrm{C}$ for $30 \mathrm{~min}$, then serum samples were collected and kept frozen until analysis.

Griess reagent consists of sulphanilamide and N-1naphtyl ethylenediamine. The method is a two-step process. The first step is the conversion of nitrate to nitrite, using nitrate reductase. The second step is the addition of Griess reagent, which converts nitrite in to the deep purple azo compound; photometric measurement of the absorbance at $540 \mathrm{~nm}$ due to this azo chromophore accurately determines the nitrite concentration (sodium nitrate is used as a standard). Protein interference is removed by treating the reacted samples with zinc sulphate and centrifuging them for $10 \mathrm{~min}$ at $2000 \mathrm{~g}$ (Schulz et al., 1999; Aksoy et al.; Ricart-Jané et al., 2002).

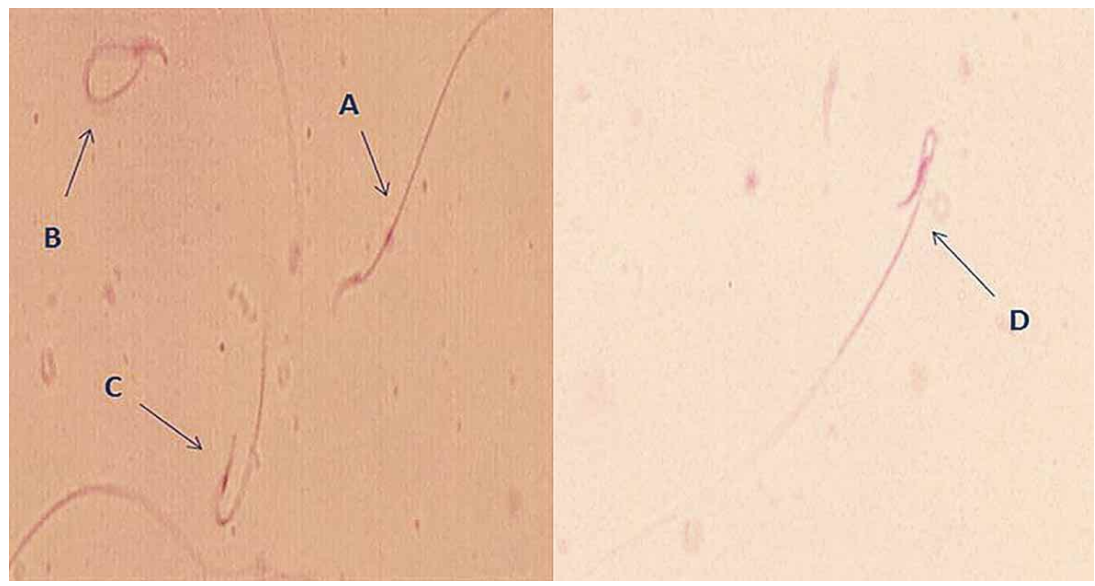

Fig. 3. Sperm morphology. Some examples of abnormal morphology (B, C, D).
Statistical Analyses. All values were expressed as mean \pm standard deviation (SD). Statistical analyses were performed by analyses of variance (ANOVA). Probability values of $<0.05$ were considered as significant.

\section{RESULTS}

Evaluation of Varicocele. All rats with varicocele showed conspicuous dilatation of the left spermatic vein with blood vein engorgement. In group $\mathrm{C}$ and also in right side in all groups no dilatation of the spermatic vein was observed.

Assessment of Sperm Parameters. The sperm parameters between groups V1 and V2 (varicocele groups) in left side had no significant difference. The sperm motility, count, and vitality of the left testis of rats in the group V1 and $\mathrm{V} 2$ decreased significantly in comparison with those of group $\mathrm{C}$ (control) $(\mathrm{P} \leq 0.05)$ but no differences were observed in morphology (normal\%), weights of testes and epididymis

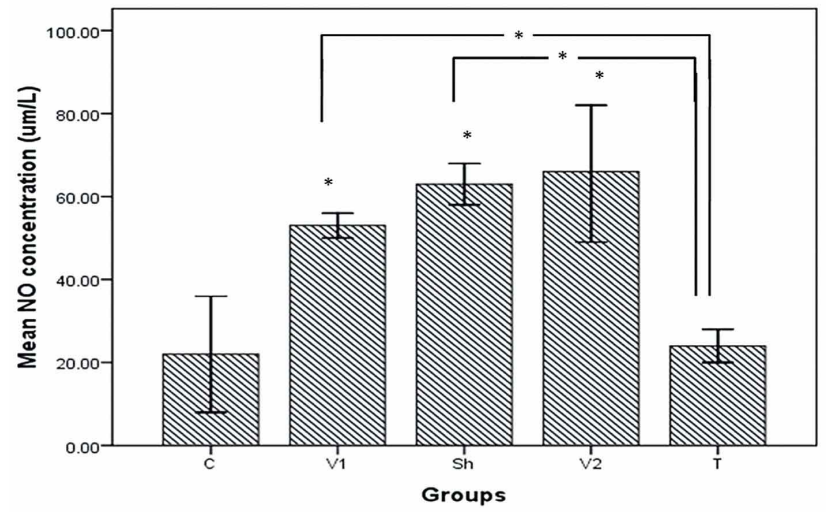

Fig. 4. Comparison the mean of NO concentration (\%) in different groups. Significant differences between groups V1 and T. Sh and T. $*=\mathrm{P} \leq 0.05$ compared with the control group. 
IZADPANAH, M.; ALIZADEH, R.; MINAEE, M. B.; HEYDARI, L.; BABATUNDE, A. \& ABBASI, M. The effects of curcumin on sperm parameters and nitric oxide production in varicocelized rats. Int. J. Morphol., 33(4):1530-1535, 2015.

Table I. Testes and Epididymis weights and Epididymal sperm count, motility, vitality and morphology in the experimental groups on the left and right sides.

\begin{tabular}{|c|c|c|c|c|c|c|c|}
\hline \multicolumn{2}{|c|}{$\begin{array}{l}\text { Sperm parameters } \\
\text { /Groups }\end{array}$} & \multirow{2}{*}{$\begin{array}{c}\text { Testis } \\
\text { w eight (mg) }\end{array}$} & \multirow{2}{*}{$\begin{array}{c}\begin{array}{c}\text { Epididy me } \\
\text { weight (mg) }\end{array} \\
0.69 \pm 0.24\end{array}$} & \multirow{2}{*}{$\begin{array}{c}\text { Sperm count. } \\
3.03 \pm 0.014\end{array}$} & \multirow{2}{*}{$\begin{array}{c}\text { Sperm } \\
\text { viability (\%) }\end{array}$} & \multirow{2}{*}{$\begin{array}{c}\begin{array}{c}\text { Normal } \\
\text { morphology (\%) }\end{array} \\
97.81 \pm 0.75\end{array}$} & \multirow{2}{*}{$\begin{array}{c}\begin{array}{c}\text { Motile sperm } \\
(\mathbf{\%})\end{array} \\
82.32 \pm 2.3\end{array}$} \\
\hline Control & Left & & & & & & \\
\hline (C) & Right & $1.26 \pm 0.03$ & $0.72 \pm 0.22$ & $3.18 \pm 0.22$ & $97.55 \pm 2.61$ & $97.74 \pm 4.81$ & $84.27 \pm 5.40$ \\
\hline Varicocele & Left & $0.99 \pm 0.16$ & $0.47 \pm 0.08$ & $1.19 \pm 0.17^{*}$ & $70.07 \pm 7.2^{*}$ & $91.89 \pm 2.5$ & $52.59 \pm 9.9^{*}$ \\
\hline (V1) & Right & $1.01 \pm 0.23$ & $0.45 \pm 0.03$ & $2.97 \pm 0.62^{*}$ & $81.33 \pm 1.26^{*}$ & $89.34 \pm 3.49$ & $67.81 \pm 4.33^{*}$ \\
\hline Varicocele & Left & $1.12 \pm 0.24$ & $0.53 \pm 0.14$ & $1.06 \pm 0.31^{\prime \prime}$ & $80.14 \pm 2.9^{*}$ & $91.12 \pm 4.4$ & $51.70 \pm 7.4$ \\
\hline (V2) & Right & $0.80 \pm 0.24$ & $0.70 \pm 0.22$ & $2.85 \pm 0.58^{*}$ & $77.71 \pm 1.1^{*}$ & $88.71 \pm 1.71$ & $60.00 \pm 1.62 *$ \\
\hline Treatment & Left & $1.43 \pm 0.49$ & $0.60 \pm 0.03$ & $2.51 \pm 0.85^{* *}$ & $90.36 \pm 1.2^{* *}$ & $93.83 \pm 4.3$ & $86.27 \pm 5.3^{* *}$ \\
\hline$(\mathrm{T})$ & Right & $1.00 \pm 0.22$ & $0.64 \pm 0.08$ & $2.65 \pm 0.62$ & $88.49 \pm 2.3^{\cdots \cdots}$ & $94.39 \pm 1.79$ & $81.56 \pm 3.57^{\ldots \cdots}$ \\
\hline Sham & Left & $1.22 \pm 0.30$ & $0.77 \pm 0.06$ & $1.59 \pm 0.11^{*}$ & $76.23 \pm 4.4^{*}$ & $86.79 \pm 2.1$ & $61.75 \pm 0.50 *$ \\
\hline (Sh) & Right & $1.22 \pm 0.30$ & $0.72 \pm 0.30$ & $2.59 \pm 0.67^{*}$ & $86.83 \pm 4.3^{*}$ & $91.9 \pm 1.42$ & $64.86 \pm 2.40^{*}$ \\
\hline
\end{tabular}

Note. Results are presented as mean (SD); * $=\mathrm{P} \leq 0.05$ compared with the control group. **= P $\leq 0.05$ compared with the V1, V2 and Sh groups.

in all groups. In group $\mathrm{T}$ (treatment) the sperm parameters of the left testes improved significantly in comparison with those of the varicocele groups (V1 and V2) ( $\mathrm{P} \leq 0.05)$. However, no significant changes were recorded between groups V1 and V2. No significant changes were recorded when varicocele and sham (Sh) groups were both compared. All parameters of the right side show no significant changes in all groups. The results have been shown in Table I.

Assessment of NO level. The mean NO concentration in the serum of varicocele groups (V1 and V2) was significantly higher than control but no significant changes were recorded between groups V1 and V2. While the NO level decreased considerably in treatment group in comparison with the varicocele groups. But no differences in NO level have been observed between the varicocele and Sham groups.

\section{DISCUSSION}

The deleterious effect of varicocele on semen parameters and infertility in men is well known; however, several questions remain unanswered regarding the exact pathophysiology of this condition. Under pathological conditions, ROS production overwhelms the antioxidants defense and causes oxidative stress (OS) (Romeo et al.; Zümrütbas et al., 2013). OS have been implicated in reduced fertility in patients with varicocele. Varicocele is related with both increased generation of nitric oxide (NO) and spermatozoal reactive species. NO that is synthesized by the enzyme NOS, with low concentration has its important biological roles in male reproductive function, but excessive production of NO have negative effects on sperm parameters quality (Romeo et al.; Ricart-Jané et al.; Ramya et al., 2011). Our study has showed a significant increase of NOx in the serum of varicocele groups. Mitropolous et al. (1996) reported that NOS activity in the serum sample of patients with varicocele was eightfold greater than the NOS contained from the peripheral serum. This study revealed that NO concentration in the seminal plasma in these patients were higher than the control (Mitropoulos et al.; Aksoy et al.). Many studies reported that there is a significant correlation between varicocele and poor sperm quality. Some show correlation with all parameters and others to some parameters only. The results of our study showed that the total sperm count, motile sperm and total vital sperms were significantly lower in varicocele groups, which is consistent with previously reported results (Hauser et al., 2001; Alizadeh et al.) while morphology, testicular weight and weight of epididymis did not change significantly. A study in 1990, conducted by WHO, showed only a decreased testes volume and lower sperm count in 9034 infertile men with varicocele, However other sperm parameters like sperm motility and morphology were not influenced in these patients (Hauser et al.). Reported results of Hanns et al., in 1991 also showed that sperm characteristics of morphology did not differ in adolescents with or without varicocele (Naughton et al., 2001). Studies have shown that better pregnancy outcomes were associated with better semen parameters (Agarwal et al., 2007). Noorafshan \& Ashkani-Esfahani in 2013 reported that Curcumin acted as an antioxidant, preventing free radical formation and lipid peroxidation in many tissues. Oguzturk et al. in 2012 showed that Curcumin can ameliorate hazardous effects of cadmium chloride $\left(\mathrm{CdCl}_{2}\right)$ on the male reproductive system in rats. In this study when we administered Curcumin, NO concentration declined significantly and sperm parameters except morphology, improved considerably in comparison with the varicocele groups (since Curcumin as an inhibitor of NOS activity is reported in many studies decreased the NO level) (Noorafshan \& Ashkani-Esfahani). Curcumin, an atoxic antioxidant, is well supported by studies that indicate it acts 
as a free radical scavenger (Oguzturk et al.; Noorafshan \& Ashkani-Esfahani). Our results are also in agreement with the previous reports on other antioxidant agents (Semercioz et al., 2003, Ghorbani et al., 2014). A recent study using melatonin intraperitoneally as an antioxidant, showed successful reduction in the testes of NO concentration in varicocelized male rats (Semercioz et al.). A report of Alizadeh et al., also showed that significant changes were observed in all the sperm parameters when Aminoguanidin (AG) wasinjected intraperitoneally into varicocelized rats. Administration of Curcumin in this experiment, reduced excessive NO production in varicocelized rats and improved sperm parameters. So as Curcumin is used as a spice in human diet, it can also be recommended to patients as a supplement in addition to varicocelectomy.

\section{CONCLUSION}

We have shown that administration of Curcumin by gavage has ameliorative effects on sperm parameters in male rats with varicocele. And also NO level can decline significantly after treatment by Curcumin. We conclude that Curcumin could be useful for the treatment of varicocele and possibly other clinical conditions involving excess free radical production.

\section{ACKNOWLEDGMENTS}

This research was supported by Tehran University of Medical Sciences.

IZADPANAH, M.; ALIZADEH, R.; MINAEE, M. B.; HEYDARI, L.; BABATUNDE, A. \& ABBASI, M. Efectos de la cúrcuma sobre los parámetros espermáticos y producción de óxido nítrico en ratas varicocelizadas. Int. J. Morphol., 33(4):1530-1535, 2015.

RESUMEN: Uno de los mecanismos propuestos por el cual los varicoceles inducen daño es la excesiva liberación de óxido nítrico $(\mathrm{ON})$. Varios estudios han demostrado el efecto del ON en la mala calidad del semen en pacientes infértiles con varicocele. Investigaciones han demostrado los efectos beneficiosos de la cúrcuma sobre los parámetros de esperma. La cúrcuma como un antioxidanteatóxico puede reducir la producción de ON. El objetivo de este estudio fue determinar el efecto de la cúrcuma en el nivel de ON e investigar si la cúrcuma puede mejorar los parámetros del semen en ratas macho. Treinta ratas macho Wistar fueron divididas aleatoriamente en 5 grupos (V1y V2 (varicocele), T (tratamiento), Sh (simulado) y C (control)). En los grupos V1, V2, T y Sh, la vena renal izquierda fue parcialmente ligada para inducir varicocele. En los grupos de V1 y V2, los parámetros de semen y nivel de ON se evaluaron a las 8 y 16 semanas respectivamente, después de la inducción de varicocele. Los grupos T y Sh recibieron diariamente 100 $\mathrm{mg} / \mathrm{kg}$ de cúrcuma y placebo durante 8 semanas, después de 2 meses de inducir el varicocele. Fueron medidos los parámetros del semen (recuento, motilidad, viabilidad y morfología espemática), peso del epidídimo y testículos, junto con la concentración del ON. El recuento, motilidad y viabilidad de los espermatozoides en los grupos V1, V2 y Sh fueron significativamente más bajos en comparación con los grupos C y T. El nivel de ON se incrementó significativamente en el suero de las ratas de los grupos V1 y V2, mientras que el suero del grupo $\mathrm{T}$, en el que se administró cúrcuma, hubo una disminución de los niveles de ON. El peso del epidídimo y testículos tuvieron cambios significativos $(\mathrm{P} \leq 0,05)$ en todos los grupos. La administración de cúrcuma como un eliminador de radicales libres, puede disminuir el nivel de $\mathrm{ON}$ y mejorar los parámetros espermáticos en ratas macho varicocelizadas.

PALABRAS CLAVE: Varicocele; Cúrcuma; Parámetros espermáticos; Rata.

\section{REFERENCES}

Agarwal, A.; Deepinder, F.; Cocuzza, M.; Agarwal, R.; Short, R. A.; Sabanegh, E. \& Marmar, J. L. Efficacy of varicocelectomy in improving semen parameters: new meta-analytical approach. Urology, 70(3):532-8, 2007.

Aksoy, H.; Aksoy, Y.; Ozbey, I.; Altuntas, I. \& Akçay, F. The relationship between varicocele and semen nitric oxide concentrations. Urol. Res., 28(6):357-9, 2000.

Alizadeh, N.; Abbasi, M.; Abolhassani, F.; Amidi, F.; Mahmoudi, R.; Hoshino, Y.; Sato, E. \& Ragerdikashani, I. Effects of aminoguanidine on infertile varicocelized rats: A functional and morphological study. Daru, 18(1):51-6, 2010.
Baazeem, A.; Belzile, E.; Ciampi, A.; Dohle, G.; Jarvi, K.; Salonia, A.; Weidner, W. \& Zini, A. Varicocele and male factor infertility treatment: a new meta-analysis and review of the role of varicocele repair. Eur. Urol., 60(4):796-808, 2011.

Cam, K.; Simsek, F.; Yuksel, M.; Turkeri, L.; Haklar, G.; Yalcin, S. $\&$ Akdas, A. The role of reactive oxygen species and apoptosis in the pathogenesis of varicocele in a rat model and efficiency of vitamin E treatment. Int. J. Androl., 27(4):228-33, 2004.

Cheng, D.; Zheng, X. M.; Li, S. W.; Yang, Z. W. \& Hu, L. Q. Effects of epidermal growth factor on sperm content and motility of rats with surgically induced varicoceles. Asian J. Androl., 8(6):713-7, 2006. 
Eisenberg, M. L. \& Lipshultz, L. I. Varicocele-induced infertility: Newer insights into its pathophysiology. Indian J. Urol., 27(1):58-64, 2011.

Farombi, E. O.; Abarikwu, S. O.; Adedara, I. A. \& Oyeyemi, M. O. Curcumin and kolaviron ameliorate di-n-butylphthalateinduced testicular damage in rats. Basic Clin. Pharmacol. Toxicol., 100(1):43-8, 2007.

Ghorbani, R.; Mokhtari, T.; Khazaei, M.; Salahshoor, M. R.; Jalili, C. \& Bakhtiari, M. The effect of walnut on the weight, blood glucose and sex hormones of diabetic male rats. Int. J. Morphol., 32(3):833-8, 2014.

Hauser, R.; Paz, G.; Botchan, A.; Yogev, L. \& Yavetz, H. Varicocele: effect on sperm functions. Hum. Reprod. Update, 7(5):482-5, 2001 .

Khaki, A.; Fathiazad, F.; Nouri, M.; Khaki, A.; Maleki, N. A.; Khamnei, H. J. \& Ahmadi, P. Beneficial effects of quercetin on sperm parameters in streptozotocin-induced diabetic male rats. Phytother. Res., 24(9):1285-91, 2010.

Marmar, J. L. The pathophysiology of varicoceles in the light of current molecular and genetic information. Hum. Reprod. Update, 7(5):461-72, 2001.

Mitropoulos, D.; Deliconstantinos, G.; Zervas, A.; Villiotou, V.; Dimopoulos, C. \& Stavrides, J. Nitric oxide synthase and xanthine oxidase activities in the spermatic vein of patients with varicocele: a potential role for nitric oxide and peroxynitrite in sperm dysfunction. J. Urol., 156(6):1952-8, 1996.

Naughton, C. K.; Nangia, A. K. \& Agarwal, A. Pathophysiology of varicoceles in male infertility. Hum. Reprod. Update, 7(5):473-81, 2001.

Noorafshan, A. \& Ashkani-Esfahani, S. A review of therapeutic effects of curcumin. Curr. Pharm. Des., 19(11):2032-46, 2013.

Oguzturk, H.; Ciftci, O.; Aydin, M.; Timurkaan, N.; Beytur, A. \& Yilmaz, F. Ameliorative effects of curcumin against acute cadmium toxicity on male reproductive system in rats. Andrologia, 44(4):243-9, 2012.

Ramya, T.; Misro, M. M.; Sinha, D. Nandan, D. \& Mithal, S. Altered levels of seminal nitric oxide, nitric oxide synthase, and enzymatic antioxidants and their association with sperm function in infertile subjects. Fertil. Steril., 95(1):135-40, 2011.

Ricart-Jané, D.; Llobera, M. \& López-Tejero, M. D. Anticoagulants and other preanalytical factors interfere in plasma nitrate/nitrite quantification by the Griess method. Nitric Oxide, 6(2):17885,2002

Romeo, C.; Ientile, R.; Santoro, G.; Impellizzeri, P.; Turiaco, N.; Impalà, P.; Cifalà, S.; Cutroneo, G.; Trimarchi, F. \& Gentile,
C. Nitric oxide production is increased in the spermatic veins of adolescents with left idiophatic varicocele. J. Pediatr, Surg., 36(2):389-93, 2001.

Schauer, I.; Madersbacher, S.; Jost, R.; Hübner, W. A. \& Imhof, M. The impact of varicocelectomy on sperm parameters: a meta-analysis. J. Urol., 187(5):1540-7, 2012.

Schulz, K.; Kerber, S. \& Kelm, M. Reevaluation of the Griess method for determining NO/NO2- in aqueous and proteincontaining samples. Nitric Oxide, 3(3):225-34, 1999.

Semercioz, A.; Onur, R.; Ogras, S. \& Orhan, I. Effects of melatonin on testicular tissue nitric oxide level and antioxidant enzyme activities in experimentally induced left varicocele. Neuro Endocrinol. Lett., 24(1-2):86-90, 2003.

Sikka, S. C.; Rajasekaran, M. \& Hellstrom, W. J. Role of oxidative stress and antioxidants in male infertility. J. Androl., 16(6):4648, 1995.

Turner, T. T. The study of varicocele through the use of animal models. Hum. Reprod. Update, 7(1):78-84, 2001.

Zümrütbas, A. E.; Gülpınar, Ö.; Mermerkaya, M.; Süer, E. \& Yaman, Ö. The effect of varicocele on sperm morphology and DNA maturity: does acridine orange staining facilitate diagnosis? Turk. J. Urol., 39(3):165-9, 2013.

Correspondence to:

Mehdi Abbasi

Poorsina Street

Department Anatomy School Of Medicine

Tehran University of Medical Science

Tehran

IRAN

Email: abbasima@sina.tums.ac.ir

Received: 02-06-2015

Accepted: 20-08-2015 